University of Nebraska - Lincoln

DigitalCommons@University of Nebraska - Lincoln

\title{
Improved Mapping of National Atmospheric Deposition Program Wet-deposition in Complex Terrain using PRISM-gridded Data Sets
}

Natalie E. Latysh

U.S. Geological Survey, nlatysh@usgs.gov

Gregory Alan Wetherbee

U.S. Geological Survey

Follow this and additional works at: https://digitalcommons.unl.edu/usgsstaffpub

Latysh, Natalie E. and Wetherbee, Gregory Alan, "Improved Mapping of National Atmospheric Deposition Program Wet-deposition in Complex Terrain using PRISM-gridded Data Sets" (2012). USGS Staff -Published Research. 736.

https://digitalcommons.unl.edu/usgsstaffpub/736

This Article is brought to you for free and open access by the US Geological Survey at DigitalCommons@University of Nebraska - Lincoln. It has been accepted for inclusion in USGS Staff -- Published Research by an authorized administrator of DigitalCommons@University of Nebraska - Lincoln. 


\title{
Improved mapping of National Atmospheric Deposition Program wet-deposition in complex terrain using PRISM-gridded data sets
}

\author{
Natalie E. Latysh • Gregory Alan Wetherbee
}

This article is a U.S. government work, and is not subject to copyright in the United States.

Received: 27 September 2010 / Accepted: 14 March 2011 / Published online: 8 April 2011

(C) Springer Science+Business Media B.V. (outside the USA) 2011

\begin{abstract}
High-elevation regions in the United States lack detailed atmospheric wet-deposition data. The National Atmospheric Deposition Program/National Trends Network (NADP/NTN) measures and reports precipitation amounts and chemical constituent concentration and deposition data for the United States on annual isopleth maps using inverse distance weighted (IDW) interpolation methods. This interpolation for unsampled areas does not account for topographic influences. Therefore, NADP/NTN isopleth maps lack detail and potentially underestimate wet deposition in high-elevation regions. The NADP/NTN wet-deposition maps may be improved using precipitation grids generated by other networks. The Parameter-elevation Regressions on Independent Slopes Model (PRISM) produces digital grids of precipitation estimates from many precipitation-monitoring networks and incorporates influences of topographical and geo-
\end{abstract}

N. E. Latysh $(\varangle)$

Core Science Systems, U.S. Geological Survey,

P.O. Box 25046, Denver Federal Center,

M.S. 306, Denver, CO 80225, USA

e-mail: nlatysh@usgs.gov

G. A. Wetherbee

Office of Water Quality, U.S. Geological Survey,

P.O. Box 25046, Denver Federal Center,

M.S. 401, Denver, CO 80225, USA graphical features. Because NADP/NTN ion concentrations do not vary with elevation as much as precipitation depths, PRISM is used with unadjusted NADP/NTN data in this paper to calculate ion wet deposition in complex terrain to yield more accurate and detailed isopleth deposition maps in complex terrain. PRISM precipitation estimates generally exceed NADP/NTN precipitation estimates for coastal and mountainous regions in the western United States. NADP/NTN precipitation estimates generally exceed PRISM precipitation estimates for leeward mountainous regions in Washington, Oregon, and Nevada, where abrupt changes in precipitation depths induced by topography are not depicted by IDW interpolation. PRISM-based deposition estimates for nitrate can exceed NADP/NTN estimates by more than $100 \%$ for mountainous regions in the western United States.

Keywords PRISM • Atmospheric wet-deposition $\cdot$ Precipitation $\cdot$ National Atmospheric Deposition Program

\section{Introduction}

A lack of detailed climatic and chemical depositional data for mountainous regions in the United States complicates estimation of the effects of atmospheric deposition from anthropogenic and 
natural inputs for these low-nutrient, sensitive ecosystems (Fenn et al. 2003), many of which are located within federally designated Class I wilderness areas and are protected under the Clean Air Act (NAPAP 2005). High-elevation regions of the western United States are especially sensitive to atmospheric deposition due to thin soils, large bedrock exposures, and episodic acidification from seasonal runoff (NAPAP 2005).

The National Atmospheric Deposition Program/National Trends Network (NADP/NTN) collects precipitation samples for chemical analyses, which are used to monitor long-term trends in atmospheric wet-deposition across the United States. Collecting accurate information is imperative for assessing the effects of Title IV of the Clean Air Act Amendments (NAPAP 2005), and establishing critical load thresholds (Williams and Tonnessen 2000).

The NADP/NTN currently (2009) uses geographic information systems (GIS) to produce annual isopleth maps showing precipitationweighted mean concentration and wet deposition for major ions and hydrogen ion across the United States. Although NADP/NTN sites are widely distributed and located in each of the 48 contiguous states, their spatial distribution is not uniform and has less spatial density in mountainous areas (Fenn et al. 2003; Ingersoll et al. 2001). In some mountainous regions, the isopleth maps lack detail due to the small number of sites that meet stringent NADP data-completeness criteria, which is common for snow-dominated highelevation sites. Thus, data collected from surrounding, lower-elevation NADP/NTN sites are extrapolated across mountainous areas using the inverse distance weighted (IDW) interpolation, which does not account for elevation-induced effects on precipitation. Accordingly, the isopleth maps presumably underestimate precipitation amounts and wet deposition of analytes in mountainous terrain.

The Parameter-elevation Regressions on Independent Slopes Model (PRISM), developed by researchers at Oregon State University, is a system that produces continuous, regularly spaced digital grids of climatic data estimates (Daly et al.
1994, 2002, 2008). PRISM extrapolates environmental variables from point measurements across the United States and applies to these variables a digital elevation model (DEM) and other spatially gridded data for estimating climate parameters in mountainous terrain and coastal areas. Precipitation patterns in the western United States are strongly influenced by mountainous terrain (Daly 1998), which affects airflow and cloud development (Rife 1996). PRISM precipitation grids, in conjunction with NADP/NTN concentration grids for major ions, are presumed to produce more detailed and potentially more realistic deposition isopleth maps, especially for complex terrain, than the maps currently produced by the NADP. In 2006, PRISM used over 13,000 point measurements (Daly et al. 2008), compared to 195 point measurements used by the NADP (Roger Claybrooke, NADP, written commun., June 2008), to produce annual precipitation estimates for the conterminous United States. Nanus et al. (2003) used PRISM grids to create wet-deposition maps for the Rocky Mountains, which are more detailed than maps produced by the NADP.

This study compares wet-deposition estimates determined by the IDW extrapolation technique used by the NADP with wet-deposition estimates that use precipitation amounts determined by PRISM. To determine total deposition, both methods use analyte concentrations measured by the NADP/NTN, which are in strong agreement with annual snowpack concentrations measured in the Rocky Mountains (Clow et al. 2002). Because NADP/NTN chemical concentration data are specifically quality assured (Wetherbee et al. 2005a, 2006), potential underestimates by the NADP of chemical loading to high-elevation regions may be caused by the IDW extrapolation technique used to estimate precipitation. Using more rigorous precipitation models, such as PRISM, which rely on dense station-monitoring networks, may enhance deposition estimates for complex, high-elevation terrain, which offer few direct measurements by the NADP. The intent of this work is to increase the resolution of deposition over shorter linear distances in complex terrain. 


\section{Background}

NADP/NTN high-altitude monitoring

NADP's mission of providing regionally representative wet-deposition data is achieved by monitoring the amount and chemistry of precipitation at as many as 250 fixed sites, many of which are in remote locations, away from emission-point sources. The number of active sites varies annually due to funding. Precipitation samples collected at each NADP/NTN site are analyzed for major ions, $\mathrm{pH}$, and specific conductance, and precipitationdepth amounts are recorded. To avoid dry deposition collection, an automated sampler collects precipitation for chemical analysis using a sensor, which triggers collector-lid openings and closings during the onset and cessation of precipitation. Weekly precipitation depth is recorded by a rain gage and used to calculate the annual deposition of chemical constituents measured at the site. Precipitation depth is multiplied by analyte concentration to determine total wet deposition (Dossett and Bowersox 1999).

Sample collection at high-elevation sites (above 3,000 meters $(\mathrm{m})$ ) in western United States is hindered by limited site access, low temperatures, high winds, and increased precipitation, which diminish equipment performance and challenge collection of complete samples. The lack of alternating current power in remote locations and a reliance on solar/direct current power also encumber sample collection. Commonly, high-elevation regions receive a higher percentage of frozen precipitation (snow) than lower-elevation areas. Snow is often driven and redistributed by wind, which hinders accurate determination of precipitation amounts. The precipitation sample collector has a sensor with limited sensitivity to light and blowing snow, which sometimes causes failures or delays in collector-lid openings, thus limiting the collection of snow (Williams et al. 1998).

\section{Data completeness}

NADP/NTN data-completeness criteria ensure that an acceptable number of valid chemical sam- ples and precipitation amounts obtained with properly functioning wet-deposition collectors and precipitation gages are used for isopleth mapping (a complete explanation is available in NADP 2008). Data for high-altitude NADP/ NTN sites are often excluded from annual isopleth maps because they fail to meet the completeness criteria (NADP 2008) due to the challenges of monitoring in extreme weather conditions.

Before 2009, a data-completeness criterion (Criterion 4) existed that required consistent collection by the rain gage and collector. Highelevation sites rarely met this criterion, which required that the total precipitation as measured from the sample volume be at least $75 \%$ of the total precipitation measured by the rain gage for all valid samples on an annual basis (NADP 2008). Evaluation of NADP data resulted in the elimination of Criterion 4 by the NADP in 2008, and that evaluation created interest in development of better methods to represent NADP deposition data for high-elevation regions.

Currently, 28 NADP/NTN sites are located above 2,000 meters elevation above mean sea level in the contiguous United States. Fourteen of these sites were excluded from annual isopleth maps for at least 4 years between 1994 and 2006 (30\% of the study period), and six of these sites were not included on any isopleth maps during the same time period due to the failure of satisfying Criterion 4 snow catch requirements. Disqualification of high-altitude NADP/NTN sites and omission of collected data further diminishes quantification of atmospheric deposition in areas of higher elevation.

\section{Sample catch efficiency}

Sample collectors, which provide volume measurement, often collect less precipitation than rain gages because they are not wind-shielded and may not collect a portion representative of an entire event due to insensitive precipitation sensors. NADP siting criteria prohibit the placement of large objects taller than $1 \mathrm{~m}$, such as windshields, within $5 \mathrm{~m}$ of a collector (Dossett and Bowersox 1999) to avoid sample contamination from 
precipitation splashing off nearby surfaces and collection anomalies resulting from air turbulence and eddy currents induced by surrounding objects. Exclusive wind-shielding of the rain gage induces a discrepancy between the rain gage and collector for collected precipitation amounts.

Despite wind-shielding the rain gage, accurate measurements of frozen precipitation by the NADP remain problematic (Marks et al. 1988). Researchers using NADP data have applied correction factors to NADP precipitation depths to account for the undercatch of snow by the rain gage (Stohlgren et al. 1991). Overestimation of snow catch by the NADP, due to wind entrainment not associated with storms, has also been observed at snow-dominated, high-elevation sites as explained by Williams et al. (1998).

\section{NADP data interpolation}

The NADP/NTN currently produces annual isopleth maps showing precipitation-weighted mean concentration and wet-deposition data for calcium, magnesium, potassium, sodium, ammonium, chloride, nitrate, total $\mathrm{N}$ (nitrate plus ammonium), sulfate, and hydrogen ion for the contiguous United States (NADP 2009). Chemical concentrations and precipitation depths measured at NADP/NTN sites are spatially extrapolated by IDW interpolation to areas where direct measurements are not made. For IDW interpolation, direct measurements within a 500-kilometer $(\mathrm{km})$ radius are used to calculate weighted average values for unsampled areas. Values measured farther from the interpolated point exert less influence in the calculation than values measured at closer sites. The paucity of NADP/NTN sites in mountainous regions, the difficulty of collecting representative samples, and the use of a large search radius for IDW interpolation compound the problem of decreased isopleth resolution for mountainous regions on NADP maps.

For NADP/NTN isopleth maps, chemical concentrations and precipitation values are interpolated for most of the nation's mountain regions from surrounding NADP/NTN sites, which are typically located at lower elevations that receive less precipitation. Complex mountainous terrain creates microclimates and diverse precipitation patterns that vary over short distances. Precipitation generally increases with elevation because of orographic effects. Mountains also typically create rain shadows on their lee sides. However, precipitation amounts in mountainous terrain are influenced by storm types, storm trajectories, and climatic fluctuations, and may not always exceed amounts received by surrounding lower-elevation terrain (Dettinger et al. 2004). Therefore, IDW interpolation of wet deposition may not be best suited for estimating mountainous precipitation patterns because it only analyzes the horizontal distance to a point measurement during calculation and does not incorporate climatic effects of elevation, slope orientation, and other physical attributes of the landscape (Daly 2006).

\section{PRISM data interpolation}

The PRISM interpolation method calculates a climate parameter-elevation regression for each grid cell in a DEM (Daly et al. 2008). Precipitation measured at stations across the conterminous United States is used with PRISM interpolation to generate annual precipitation grids for the conterminous United States. Interpolating precipitation for a grid cell using PRISM requires weighting measurements from nearby stations based on their similarity of location, coastal proximity, elevation, slope aspect, terrain steepness, dominant storm trajectory, potential for atmospheric inversion, and influences from surrounding complex terrain to the interpolated area (Daly et al. 2008). PRISM's use of data derived from a dense network of stations and its regard for physiographic features for generating climate grids have proven superior to other commonly used climatic models such as WorldClim and Daymet, especially for coastal and mountainous areas (Daly et al. 2008). PRISM estimates are the official climatic data (including precipitation, temperature, snowfall, degree days, dew point) used by the U.S. Department of Agriculture (URL: http://www.wcc.nrcs.usda.gov/climate/ prism.html, accessed 02/01/2011).

Data used for generating PRISM precipitation grids are mostly derived from: (1) National Weather Service Cooperative Observer Program (NWS COOP), (2) Snowpack Telemetry 
(SNOTEL) managed by the U.S. Department of Agriculture Natural Resources Conservation Service, (3) Automated Surface Observing System, a joint effort of the NWS, the Federal Aviation Administration, and the Department of Defense, and (4) other federal, state, and local weather networks (Daly et al. 2008). PRISM has been used to show effects of elevation on precipitation and ion concentrations in the Rocky Mountain region (Nanus et al. 2003) and for hydrologic model calibration by the NWS River Forecast Center (URL: http://www.cnrfc.noaa.gov/products/ rfcprismuse.pdf, accessed 02/01/2011). The addition of NADP data for generating PRISM precipitation grids may increase data density and benefit the modeling techniques used to estimate precipitation.

\section{Methods}

Integrating NADP and PRISM datasets

Using GIS, the NADP/NTN produces annual grids, in $2.5 \times 2.5$ kilometer $\left(\mathrm{km}, 6.25-\mathrm{km}^{2}\right)$ resolution, and isopleth maps for the conterminous United States showing: (1) precipitation-weighted mean concentration for each measured ion (which is calculated as the sum of the product of weekly precipitation depth and concentration measurements divided by the sum of the weekly precipitation depths; milligrams per liter, mg/L), (2) precipitation depth (centimeters, $\mathrm{cm}$ ), and (3) deposition of each measured ion (kilograms per hectare, $\mathrm{kg} / \mathrm{ha}$ ), which is calculated by multiplying the annual precipitation-weighted mean concentration by the total annual precipitation depth and a unit correction factor at each site $(\mathrm{mg} / \mathrm{L} \cdot \mathrm{cm} \cdot 0.1)$. NADP/NTN isopleth maps showing the annual deposition of each measured ion are generated by IDW interpolation of the site-specific deposition values (Fig. 1). Annual NADP/NTN isopleth maps and grids are available at: http://nadp.sws.uiuc.edu/NTN/maps.aspx.

The PRISM deposition grids were generated by multiplying PRISM precipitation grids (resolution of approximately $4 \mathrm{~km}$ ), in $\mathrm{cm}$ (obtained from http://www.prism.oregonstate.edu/, accessed 02/01/2011), by the NADP precipitation-weighted mean concentration grids, which were multiplied by 0.1 to obtain deposition in kilograms per hectare. PRISM produces annual precipitation grids using $3 \mathrm{~km} \times 5 \mathrm{~km}$ grid spacing. An example is the PRISM nitrate $\left(\mathrm{NO}_{3}\right)$ deposition
Fig. 1 Schematic example showing calculation of an annual deposition isopleth map generated by multiplying the PRISM precipitation grid by the NADP/NTN precipitation-weighted mean concentration grid for each ion and multiplied by 0.1 to yield a calculation in kilograms per hectare

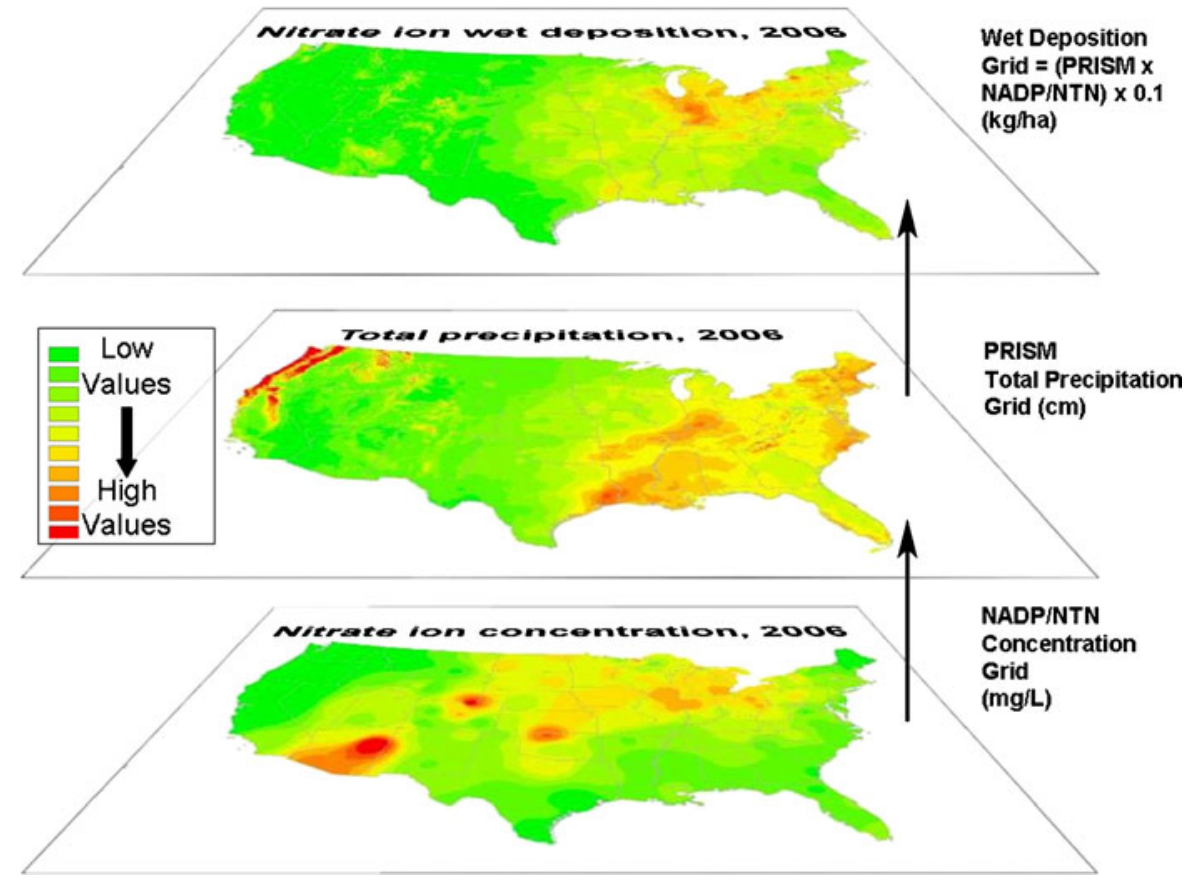


grid (Fig. 1). This method produced higher deposition estimates for most constituents than the IDW method, especially for coastal and mountainous areas of the western United States (west of $100^{\circ} 00^{\prime} 00^{\prime \prime}$ longitude, mid-Nebraska), such as the Sierra Nevada and Rocky Mountains.

NADP/NTN precipitation and deposition data collected during 2006 were compared with the PRISM 4-km precipitation-grid product for 2006. Although precipitation was variable throughout the United States during 2006, the overall annual precipitation was near the long-term annual mean for the country (URL: http://www.ncdc.noaa.gov/ oa/climate/research/2006/ann/us-summary.html\# precip, accessed 02/01/2011). Spatial differences between PRISM and NADP annual $\mathrm{NO}_{3}$ wetdeposition estimates illustrate this point later in this paper.

Comparing and combining two grids, or rasters, requires adequate cell resolution. Before comparing the NADP and PRISM rasters, reported in $6.25-\mathrm{km}^{2}(2.5 \mathrm{~km} \times 2.5 \mathrm{~km}$ grid spacing $)$ and approximately $15-\mathrm{km}^{2}$ (approximately $3 \mathrm{~km} \times$ $5 \mathrm{~km}$ grid spacing) grid cells, respectively, the NADP grid was automatically resampled by GIS to PRISM's coarser grid size, which resulted in some loss of data resolution. The nearest neighbor assignment was used to resample NADP raster data. This method identified the center of the larger grid cells in the output raster and assigned these cells the variable (precipitation, analyte deposition) values recorded for the nearest cell centers in the input raster (URL: http://webhelp. esri.com/arcgisdesktop/9.2/index.cfm?TopicName= Cell_size_and_resampling_in_analysis, accessed 02/ 01/2011). Potential variability and bias resulting from comparison of the $15-\mathrm{km}^{2}$ PRISM grid and the $6.25-\mathrm{km}^{2}$ NADP grid were not evaluated.

\section{Variation of concentrations}

with elevation-Rocky Mountains

Warren et al. (1992) evaluated the effects of precipitation type and site elevation on weekly NADP/NTN sulfate concentrations using data from six paired sites in the Rocky Mountains and concluded that: (a) average weekly sulfate concentrations in snow are consistently lower than in rain, and (b) average weekly sulfate concentrations in snow were higher at lower-elevation sites than at higher elevation sites, but a similar relation for rain was not well established. With these conclusions, adjustment of weekly wet-deposition concentrations for elevation might be important for accurate mapping. However, NADP compiles the weekly data into isopleth maps of annual precipitation-weighted mean concentration and total annual deposition. Therefore, annual precipitationweighted mean concentration estimates for the same six pairs of sites: $\mathrm{CO} 02 / \mathrm{CO} 94, \mathrm{CO} 92 / \mathrm{CO} 08$, CO98/CO19, CO93/CO97, CO95/CO96, and WY02/WY97 (Fig. 2) were compared using a longer period of record than used by Warren et al.

The average period of record available for each site was $20 \pm 3$ years between 1985 and 2007, except for the CO95/CO96 paired sites, which only had a 4-year record for 1986-1989.

The dataset contains 129 sets of annual precipitation-weighted mean measurements from the paired NADP/NTN sites. Paired differences

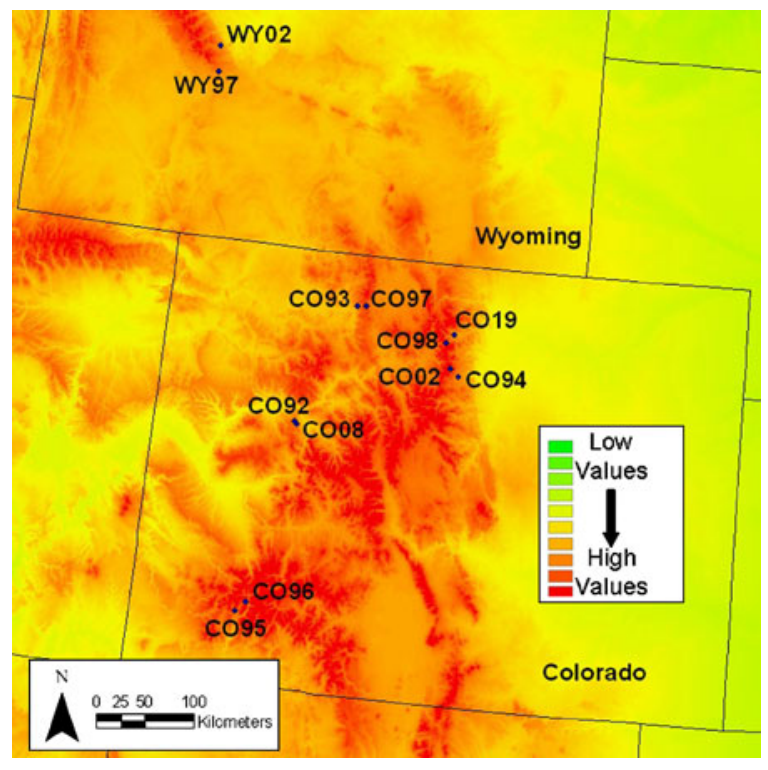

Fig. 2 Map showing locations of adjacent NADP/NTN sites at different elevations in the Rocky Mountains. Data collected at these sites were used to evaluate wet-deposition analyte concentrations. Shading represents topography; darker colors indicate higher elevation 
for precipitation-weighted annual mean concentrations, specific conductance, precipitation depth, sample volume, and catch efficiency were calculated by subtracting values for the low-elevation site from those of the high-elevation site for each pair of sites. All six pairs of sites evaluated herein and by Warren et al. (1992) are located in the Rocky Mountains. Other paired sites, such as WA21 and WA99, located in the Cascade Range, CA28 and CA75, located in the Sierra Nevada, and WY00 and WY99, located in the Rocky Mountains, either have few available data with shorter periods of record, are not considered to be located at high elevations, or are located at similar elevations. Therefore, no data from other sites in complex terrain were suitable for this analysis.

\section{Results and discussion}

\section{Variation of concentrations with elevation}

Table 1 shows results of the sign test (Kanji 1993) used to evaluate differences between annual precipitation-weighted mean concentrations for paired NADP/NTN sites. The null hypothesis states that the median difference is not significantly different from zero. The alternative hypothesis states that the median difference is significantly different from zero with $90 \%$ confidence. The italicized $p$ values in Table 1 indicate where sitespecific median concentration differences are significantly different from zero.

The results in Table 1 are varied. For example, annual mean nitrate concentration significantly differs between the high-elevation and low-elevation sites at five of the six pairs of sites. Therefore, the blanket assumption that wetdeposition concentrations are independent of site land-surface elevation does not hold true for nitrate at these paired locations. Conversely, annual mean calcium, magnesium, sodium, and hydrogen ion concentrations significantly differ between the high-elevation and low-elevation sites at two of the six pairs of sites. Furthermore, different paired sites indicate significantly different annual mean concentrations for different constituents. Reviewers of this work point out that these results are expected given all precipitation types were included in these analyses. Further investigation of why some chemical species showed differences with elevation in some locations and not others that includes air pollution sources and transport patterns is needed.

Warren et al. (1992) showed that weekly wetdeposition sulfate concentrations for sites located within the same airshed are strongly correlated, but spatial variability in sulfate concentrations between airsheds exists. This important difference between airsheds enabled Warren et al.'s analysis

Table 1 Results of sign test for paired NADP/NTN sites in the Rocky Mountains

\begin{tabular}{|c|c|c|c|c|c|c|c|}
\hline \multirow{2}{*}{$\begin{array}{l}\text { Paired } \\
\text { NADP sites } \\
\end{array}$} & \multirow{2}{*}{$\begin{array}{l}\text { Site elevation } \\
\text { difference (meters) }\end{array}$} & \multirow{2}{*}{$\begin{array}{l}\text { Period of } \\
\text { record (years) }\end{array}$} & \multicolumn{5}{|c|}{$p$ value: probability of incorrect rejection of Ho analyte } \\
\hline & & & $\mathrm{Ca}$ & $\mathrm{Mg}$ & $\mathrm{Na}$ & $\mathrm{K}$ & $\mathrm{NH}_{4}$ \\
\hline WY02/WY97 & 347 & 20 & 0.1892 & 0.1153 & 0.0072 & 0.0044 & 0.0072 \\
\hline CO95/CO96 & 491 & 4 & 0.6250 & 1.0000 & 0.1250 & 1.0000 & 1.0000 \\
\hline CO98/CO19 & 669 & 23 & 0.0043 & 0.1338 & 1.0000 & 0.0010 & $<0.0001$ \\
\hline $\mathrm{CO} 92 / \mathrm{CO} 08$ & 704 & 18 & 0.0963 & 0.0490 & 0.8036 & 0.0010 & 0.4807 \\
\hline CO93/CO97 & 707 & 20 & 1.0000 & 1.0000 & 0.4807 & 0.6476 & 0.1671 \\
\hline \multirow[t]{2}{*}{$\mathrm{CO} 02 / \mathrm{CO} 94$} & 996 & 20 & 0.8238 & 0.0118 & 0.0044 & 0.0414 & $<0.0001$ \\
\hline & & & $\mathrm{Cl}$ & $\mathrm{NO}_{3}$ & $\mathrm{SO}_{4}$ & $\mathrm{H}$ & $\mathrm{SC}$ \\
\hline WY02/WY97 & 347 & 20 & 0.0015 & 0.0015 & 0.3833 & $<0.0001$ & $<0.0001$ \\
\hline CO95/CO96 & 491 & 4 & 0.1250 & 1.0000 & 1.0000 & 0.1250 & 0.6250 \\
\hline CO98/CO19 & 669 & 23 & 0.0169 & $<0.0001$ & $<0.0001$ & 0.4049 & $<0.0001$ \\
\hline $\mathrm{CO} 92 / \mathrm{CO} 08$ & 704 & 18 & 1.0000 & 0.0963 & 0.8145 & 1.0000 & 0.8145 \\
\hline CO93/CO97 & 707 & 20 & 0.4545 & $<0.0001$ & 0.0118 & $<0.0001$ & $<0.0001$ \\
\hline $\mathrm{CO} 02 / \mathrm{CO} 94$ & 996 & 20 & 0.0118 & 0.0004 & $<0.0001$ & 0.2632 & 0.0118 \\
\hline
\end{tabular}

Values rendered in italics denote rejection of the $H_{o}$ : median paired site annual concentration differences $=0$, at $\alpha=0.10$ 
of elevation effects using the paired sites in each of the six airsheds. Likewise, spatial trends exist in wet-deposition constituent concentrations in west to east transects across the Rocky Mountains, represented by three or four NADP/NTN sites, all of which differ appreciably in elevation. For example, wet-deposition nitrate concentrations measured at CO15 (longitude 107.7025 west), CO93 (longitude 106.7811 west), and CO22 (longitude 104.7547 west) can be shown to vary from the western slope, through the Rocky Mountains, and onto the eastern plains (Dave Clow, U.S. Geological Survey, oral and written commun., August 2009). Such spatial trends over large linear distances are already illustrated by the NADP/NTN isopleth maps, but as stated earlier, resolution of deposition over shorter linear distances in the complex terrain within such transects is not represented in NADP/NTN isopleths maps.

Distributions of the annual mean precipitationweighted concentration differences for all six pairs of sites combined, represented by boxplots in Fig. 3, indicate inconsistent biases in median concentration differences. Median differences are designated by a solid line inside the boxes. When elevation differences in annual mean concentrations for all paired sites are pooled, the sign test for $H o$ : median differences for all sites $=0$, was rejected for all constituents except sodium and hydrogen ion at the $\alpha=0.1$ significance level; indicating variation of concentrations with altitude.

The interquartile ranges of the adjacent-site annual concentration differences are small compared to the $95 \%$ confidence intervals for variability in weekly NADP/NTN measurements (Wetherbee et al. 2005b), which are expected to increase for annual measurements. Therefore, while these small differences in concentrations with altitude are statistically significant, it was considered practical to multiply PRISM annual precipitation-depth grids by the spatially interpreted NADP/NTN annual mean concentration grids without adjustment of concentrations for altitude to produce representative annual deposition isopleth maps. Development of an algorithm for the adjustment of spatially interpolated annual mean concentration grids for elevation effects is needed to further improve accuracy of annual constituent wet-deposition mapping.
Comparison of PRISM and NADP precipitation estimates

A map of the conterminous United States showing differences between the PRISM precipitation grid and the NADP precipitation grid for 2006 is shown in Fig. 4, where:

Precipitation difference

$$
=\left(\frac{\left(\mathrm{PPT}_{\left.\mathrm{PRISM}-\mathrm{PPT}_{\mathrm{NADP}}\right)}\right.}{\frac{\left(\mathrm{PPT}_{\mathrm{PRISM}}+\mathrm{PPT}_{\mathrm{NADP}}\right)}{2}}\right) \times 100 \text {, and }
$$

where:

$\begin{array}{lll}\text { PPT }_{\text {PRISM }} & \begin{array}{l}\text { PRISM interpolated } \\ (\mathrm{cm}), \text { and }\end{array} \\ \text { PPT }_{\text {NADP }} & \begin{array}{l}\text { NADP interpolated } \\ (\mathrm{cm}) .\end{array}\end{array}$

The small differences shown on the map indicate that PRISM and NADP precipitation estimates for most of the eastern United States (east of $100^{\circ} 00^{\prime} 00^{\prime \prime}$ longitude, mid-Nebraska) are similar, although NADP precipitation estimates are larger for some areas in the Appalachian Mountains. The lack of NADP/NTN sites in the eastern Texas/western Louisiana region may result in precipitation underestimation by IDW interpolation, which could induce the large differences between PRISM and NADP precipitation estimates for this pluvious, coastal region. The largest precipitation differences between PRISM and NADP estimates occur in mountainous and coastal regions of the western United States where the limited distribution of NADP/NTN sites lessens the possibility for accurately measuring variable precipitation induced by the complex terrain.

The precipitation-difference grid between PRISM and NADP estimates shown in Fig. 5 is composed of a matrix of $15-\mathrm{km}^{2}$ cells, each of which records a precipitation-difference value. Using GIS, the 2006 precipitation-difference grid was converted to an integer grid format that uses a value attribute table (VAT) to record the number of grid cells associated with each precipitation-difference value displayed on the isopleth map. The percentage of cells recording positive precipitation differences, indicating that PRISM precipitation estimates exceed NADP precipitation estimates, were calculated for 
Fig. 3 Distributions of annual precipitation-weighted mean measurement differences during 1985-2007 for paired, spatially proximal NADP/NTN sites in the Rocky Mountains that have substantially different elevations

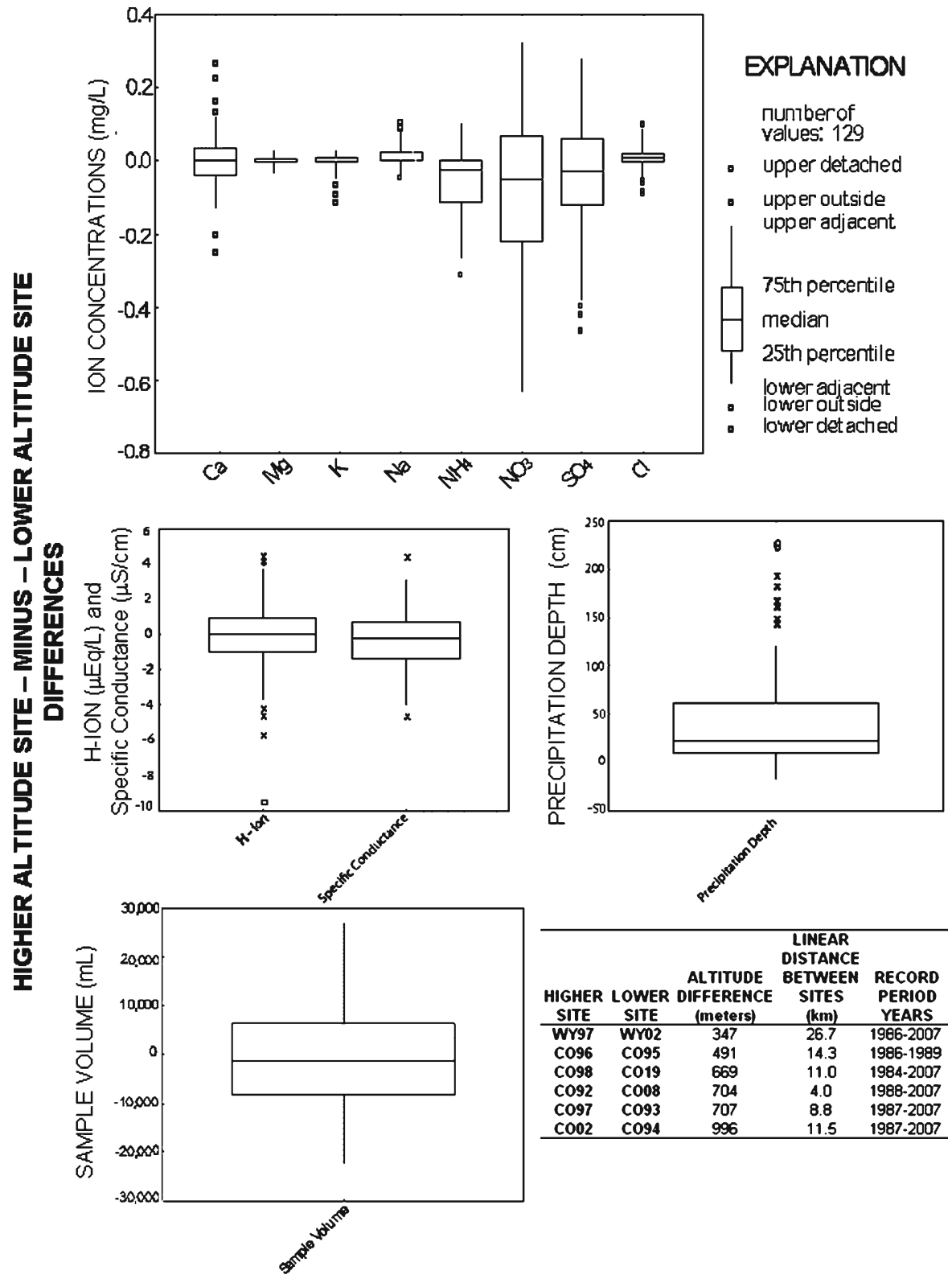

different regions in the United States. In addition, the number of grid cells within specific elevation ranges (less than 1,000; 1,000-2,000; 2,000-3,000; and greater than $3,000 \mathrm{~m}$ ) was summed to evaluate precipitation differences between PRISM and NADP for different elevations.

The percentages of grid cells recording positive precipitation differences within each of these elevation ranges are graphically compared in Fig. 5. PRISM predominantly exceeds NADP precip- itation estimates for higher elevation regions. PRISM exceeds NADP precipitation estimates more often for complex terrain regions, greater than 3,000 m, where a shortage of NADP/NTN sites exits. For terrains above 3,000 $\mathrm{m}$ in Colorado, PRISM exceeds NADP precipitation estimates for $65 \%$ of the grid cells. For terrains above 3,000 $\mathrm{m}$ in Idaho, PRISM exceeds NADP precipitation estimates for all grid cells. In 2006, as in most years, a larger number of NADP/NTN sites 
Fig. 4 Map showing percent differences between PRISM and NADP precipitation estimates (Eq. 1) for conterminous United States for 2006

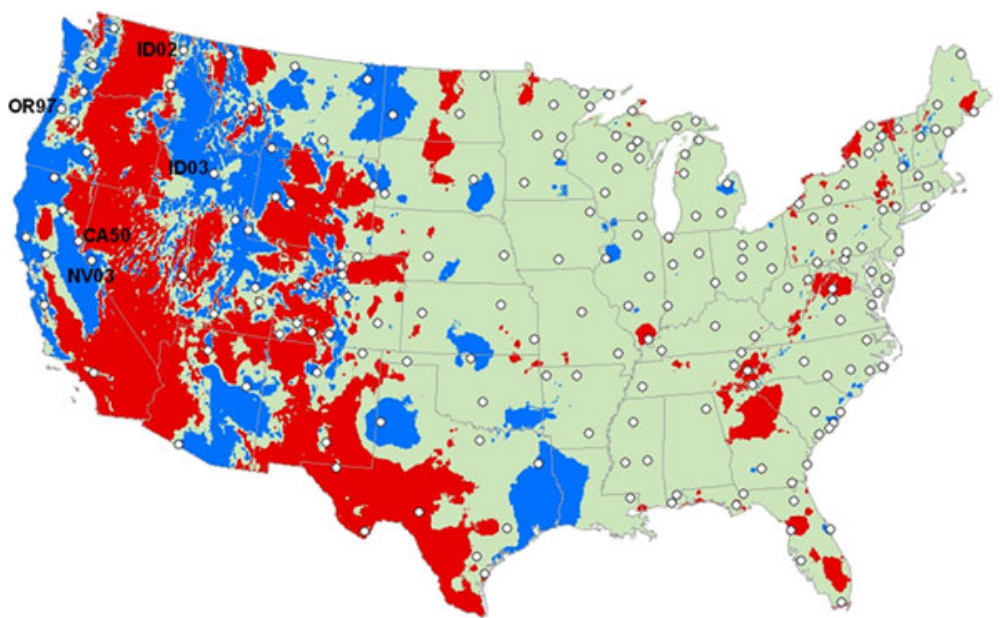

PRISM minus NADP Precipitation (\%)

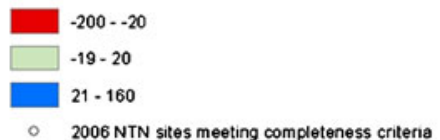

are available for IDW interpolation in Colorado (ten sites) than in Idaho (two sites).

PRISM precipitation estimates exceed NADP estimates in mountainous areas of the western United States, especially along the Continental Divide. Nonetheless, differences between 2006 PRISM and NADP precipitation-depth estimates are highly variable for Colorado (Table 2). Pre- cipitation depth is known to vary widely over short distances in mountainous terrain (Dore 2005), and the influences of topographic and geographic characteristics, which influence climatic variables (Perry and Hollis 2006), are difficult to characterize.

Predicted PRISM and interpolated NADP precipitation amounts diverge significantly within
Fig. 5 Percentage of grid cells recording positive differences between PRISM and NADP total annual precipitation estimates for 2006 for specific elevation ranges
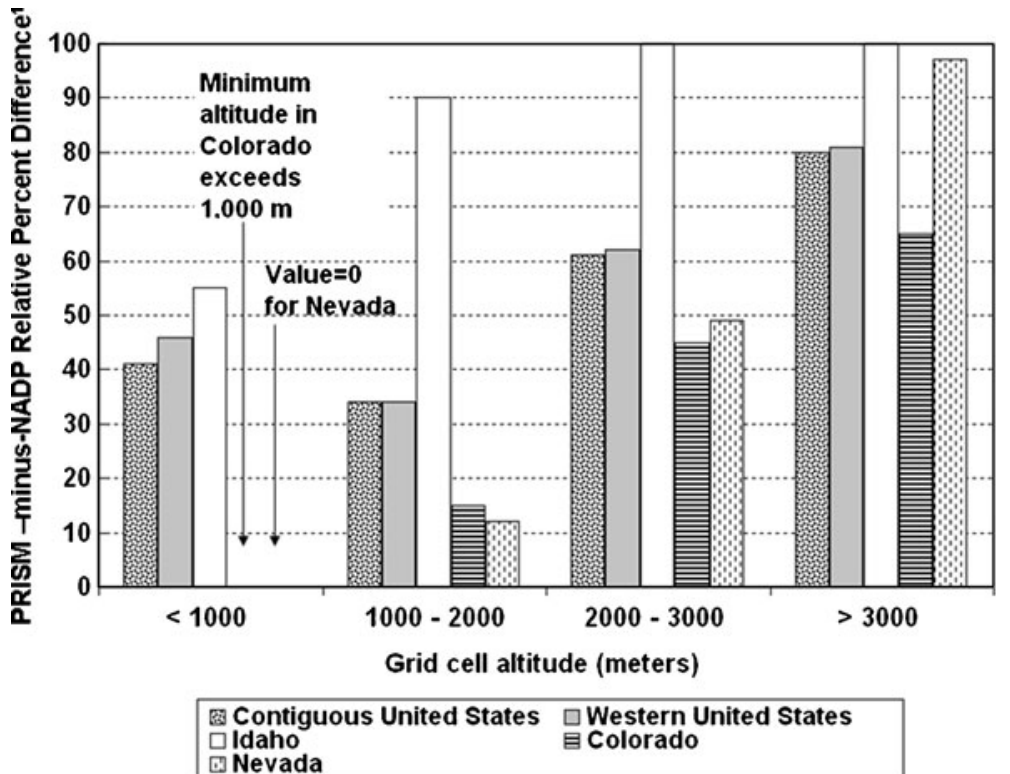

$\left.{ }^{1}[((\text { PRISM-NADP)/(PRISM+NADP }) / 2))^{*} 100\right]$ 
Table 2 Comparison of PRISM and NADP precipitation estimates for selected Colorado NADP/NTN sites for 2006

\begin{tabular}{llrrr}
\hline NADP/NTN site & $\begin{array}{l}\text { Elevation annual } \\
(\mathrm{m})\end{array}$ & $\begin{array}{l}\text { NADP/NTN 2006 } \\
\text { precipitation }(\mathrm{cm})\end{array}$ & $\begin{array}{l}\text { PRISM 2006 annual } \\
\text { precipitation }(\mathrm{cm})\end{array}$ & $\begin{array}{l}\text { PRISM-minus-NADP/NTN } \\
\text { annual (2006) precipitation } \\
\text { difference (\%) }\end{array}$ \\
\hline CO02 & 3,520 & 196 & 89 & -55 \\
CO08 & 54 & 56 & 3 & 29 \\
CO19 & 2,502 & 41 & 53 & 32 \\
CO21 & 2,490 & 160 & 57 & -11 \\
CO91 & 2,362 & 68 & 142 & 11 \\
CO92 & 3,292 & 72 & 76 & 30 \\
CO93 & 3,218 & 48 & 94 & 3 \\
CO94 & 2,538 & 89 & 83 & -7 \\
CO96 & 2,524 & 104 & 148 & 43 \\
CO97 & 3,249 & 99 & 16 \\
CO98 & 3,234 & 85 & & \\
\hline
\end{tabular}

short distances from the NADP/NTN sites due to differences in interpolation techniques. Similar NADP and PRISM data at NADP/NTN sites promote the preferred use of NADP's accurate and quality-controlled precipitation data to calculate deposition at nearly all NADP/NTN sites. However, supplanting NADP precipitation data with the PRISM data is preferred to improve resolution of interpolated ion deposition between NADP/NTN sites in mountainous terrain.

PRISM precipitation estimates also exceed NADP precipitation estimates for the northern Rocky Mountains in Idaho where NADP/NTN spatial site density is low. Data collected from two NADP/NTN sites, ID02 and ID03 (Fig. 4), satisfied the NADP completeness criteria and were available for interpolating 2006 precipitation isopleths for Idaho, which encompasses $216,000 \mathrm{~km}^{2}$ and is dominated by complex terrain. NADP/ NTN sites ID02 and ID03, located at $726 \mathrm{~m}$ and 1,807 m elevation, respectively, are at lower elevations than much of the state, which contains 50 peaks exceeding 3,000 m elevation (URL: http:// www.netstate.com/states/geography/id_geography. htm, accessed 02/01/2011). The NADP 2006 precipitation isopleth map (available at: http://nadp. sws.uiuc.edu/data/annualiso.aspx, accessed 02/01/ 2011) displays less than $40 \mathrm{~cm}$ annual precipitation for most of Idaho and does not differentiate the higher precipitation amounts received by the state's mountainous terrain. PRISM uses precipitation measurements made at approximately 80 SNOTEL sites in Idaho, along with data collected by other climatic networks, which yield greater spatial variability at higher resolution of estimated precipitation for the complex terrain in the state compared to the NADP IDW mapping.

NADP/NTN site coverage is sparse in eastern California. Data collected at NADP/NTN CA50 site (Fig. 4), situated at 1,931 m, provide the nearest precipitation measurements for the entire Sierra Nevada. CA50 is located on the eastern side of the mountain range and data collected at the site are used to extrapolate precipitation estimates for the adjacent complex terrain which includes Mount Whitney, the highest peak $(4,421 \mathrm{~m})$ in the conterminous United States, located more than $320 \mathrm{~km}$ south of the NADP/NTN site. Peak elevation in the Sierra Nevada increases from north to south, achieves maximum elevation at Mount Whitney, and gradually decreases southward, interrupted by a few intermittent peaks exceeding 3,000 m. PRISM precipitation estimates, based on 28 SNOTEL sites and other climatic gauging stations, exceed NADP estimates for the entire 650-km length of the Sierra Nevada (Fig. 4).

Large differences between PRISM and NADP precipitation estimates are evident for coastal areas in the western United States (Fig. 4). Oceanic influences along the Pacific Coast extend farther inland than along the Atlantic Coast, possibly due to the prevailing westerly winds (Munger and Eisenreich 1983) and orographic effects of the north-south-trending coastal mountain ranges, which act as barriers to oceanic air masses (Ritter 2006). NADP extrapolates precipitation depth at 
OR97 to coastal areas across a large portion of Oregon. However, PRISM, which incorporates coastal influences on precipitation in its calculations, estimates a lower total annual precipitation for the OR97 site than for both the adjacent coastal and mountainous areas. NADP precipitation estimates for sites located along the entire western coast, from southern California to the northwest coast of Washington, are lower than the precipitation estimates predicted by PRISM. Annual PRISM precipitation estimates for 2006 exceed NADP precipitation amounts by over $200 \mathrm{~cm}$ within $70 \mathrm{~km}$ of the coast in the Oregon-California border, northwest Oregon, and Olympic National Park regions.

Abrupt changes in precipitation depth are commonly observed on the leeward sides of mountains, decreasing by $75 \%$ within 10 to $20 \mathrm{~km}$ from mountainous regions receiving maximum precipitation (Daly et al. 2001). This is not readily recorded on isopleth maps produced by the NADP due to the sparse distribution of NADP/NTN sites and the large search radius used by the IDW interpolation method. Interpolated NADP precipitation values are also higher than PRISM estimates in mountainous leeward regions of the western United States. Figure 4 shows the negative difference between PRISM and NADP precipitation estimates for the leeward side of the Cascade Range in eastern Washington and eastern Oregon, an area where no NADP/NTN sites are located, and also for the leeward side of the Sierra Nevada in western Nevada, for which data collected from one NADP/NTN site (NV03) are used by the NADP for precipitation interpolation. For the NADP 2006 precipitation isopleth maps, approximately five NADP/NTN sites were used to interpolate precipitation for eastern Washington, eastern Oregon, and western Nevada: an area encompassing more than $200,000 \mathrm{~km}^{2}$.

Precipitation reported by the NADP for the leeward sides of the Cascade Range and the Sierra Nevada may be overestimated. Precipitation measurements made at proximate windward NADP/NTN sites receive greater precipitation amounts. These data are weighed more heavily by the IDW interpolation method than data collected at NADP/NTN sites located farther away in the eastern, drier regions of Washington, Oregon, and Nevada. Deposition estimates may be exaggerated by IDW interpolation for these dry, leeward regions where precipitation is low, and small differences can yield large percent differences. Few NADP/NTN sites on the leeward sides of the mountains adversely affect precipitation interpolation for these drier regions.

To illustrate the effects of windward/leeward sides of mountain ranges on PRISM-minusNADP precipitation differences, grids for the official NADP nitrate-deposition map for 2006 and the PRISM-based nitrate-deposition map for 2006 were resampled along longitudinal transects to compare estimated deposition at discrete locations spanning the windward and leeward sides of mountain ranges using the program GRID Sampler (Zerger, CSIRO Sustainable Ecosystems 2004). Results in Table 3 indicate that PRISM-minus-NADP wet-deposition differences typically are higher on the windward sides of complex terrain than on the leeward sides. Only one transect, Simmons Peak, located in the Sierra Nevada Mountains produced results where PRISM-minus-NADP differences were larger on the leeward (i.e. eastern) side of the transect, but this might be due to selection of locations of insufficient distance from the pinnacle of the transect. Large discrepancies between the PRISM- and NADP-based nitrate deposition values observed in the transects for Simmons Peak and Three Needles are likely due to the paucity of data in western and southwestern regions. Two transects in relatively homogeneous terrain in the Great Plains and Great Lakes regions were also evaluated for comparison. The Kansas City, MO and Ontario, WI transects indicate very little difference in PRISM- and NADPestimated deposition in regions with relatively low altitudes and homogeneous terrain.

Wet-deposition estimates

Mountainous terrain may receive greater analyte deposition than surrounding lowlands, due to increased precipitation resulting from orographic effects. Discrepancies between NADP and PRISM precipitation estimates can yield large analyte deposition differences. Figure $6 a$ and b, respectively, shows NADP-estimated nitrate 


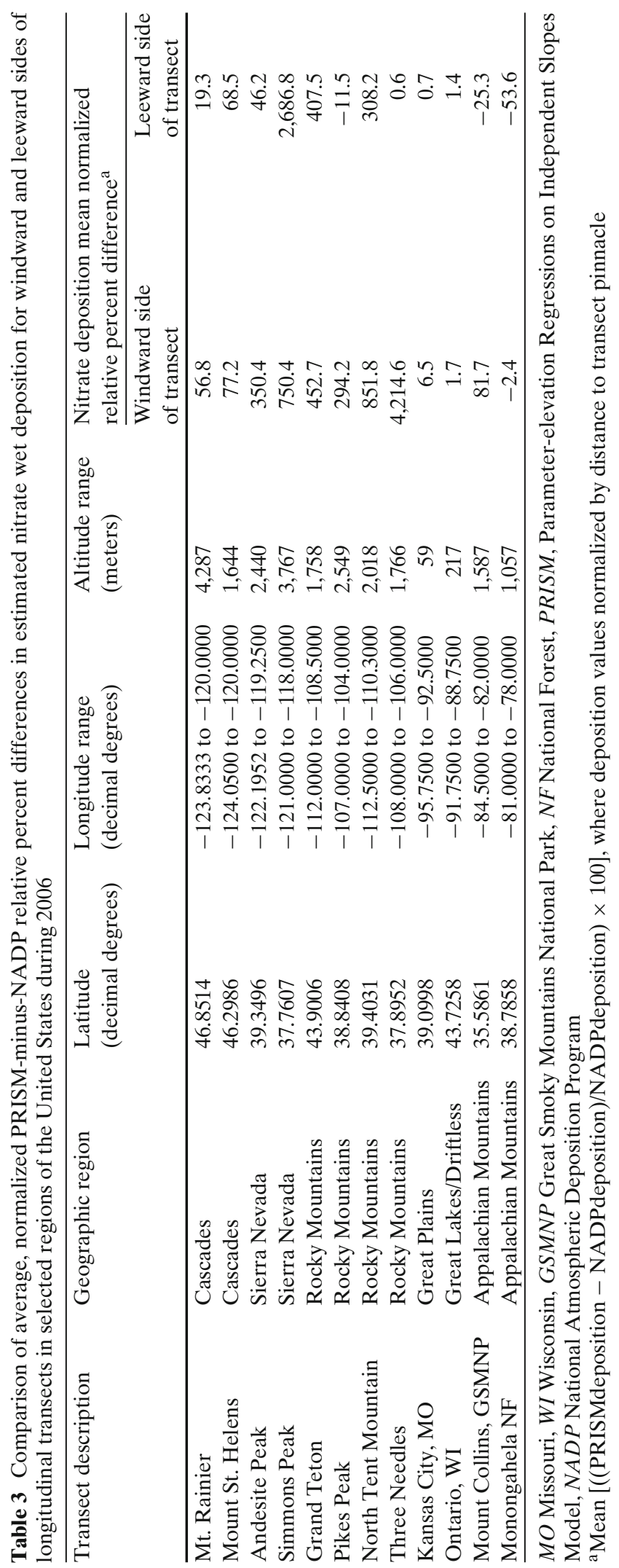


Fig. 6 a Map showing NADP annual wet-deposition estimates for nitrate for conterminous United States for 2006 (grid downloaded from URL: http://nadp.sws.uiuc.edu/ NTN/maps.aspx, accessed 02/01/2011). b Map showing PRISM annual wet-deposition estimates for nitrate for conterminous United States for 2006. Map generated by multiplying 2006 PRISM precipitation grid (downloaded from URL: http://www.prism. oregonstate.edu/, accessed 02/01/2011) by 2006 NADP nitrate-concentration grid (downloaded from URL: http://nadp.sws.uiuc.edu/ NTN/maps.aspx, accessed 02/01/2011). с Map showing differences between PRISM and NADP annual wet-deposition estimates for nitrate for conterminous United States for 2006
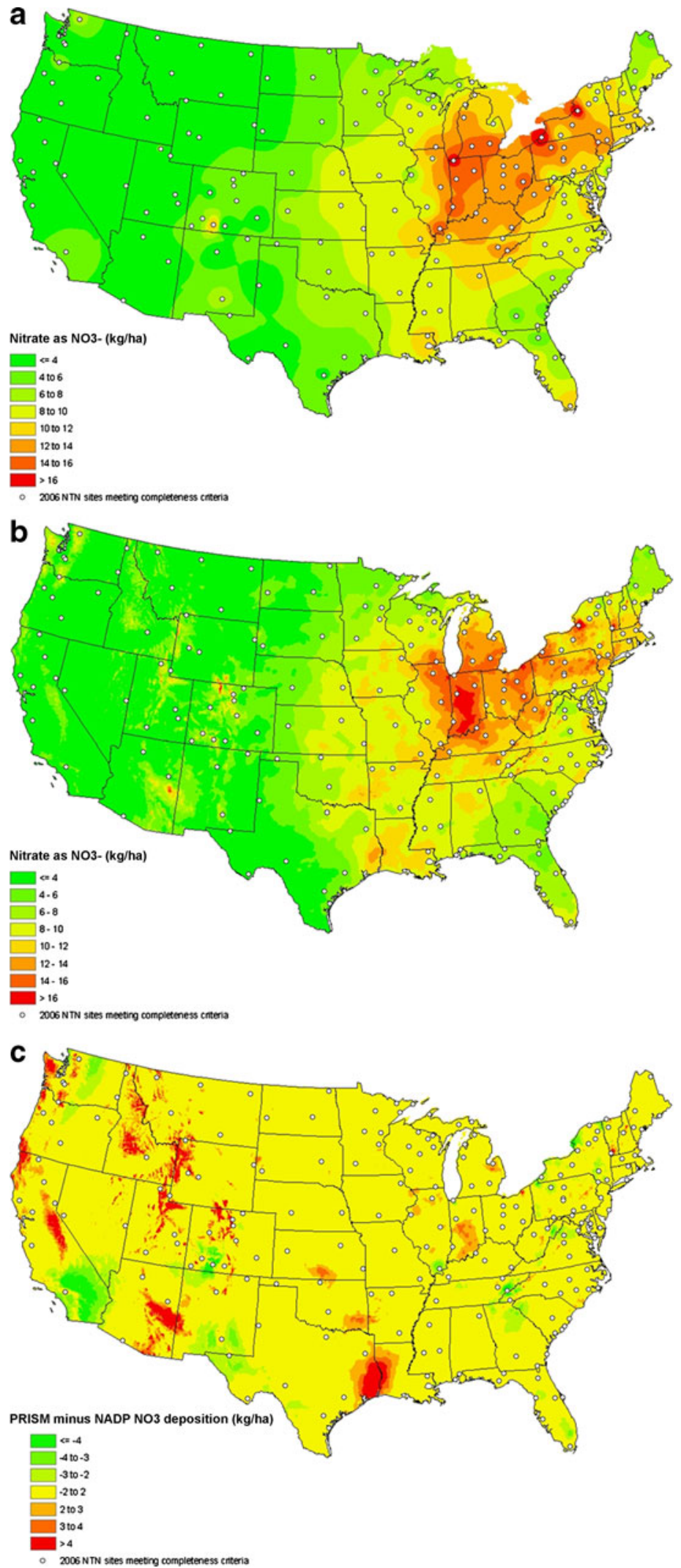
deposition and PRISM-estimated nitrate deposition. Figure $6 \mathrm{c}$ shows the differences between PRISM deposition and NADP deposition of nitrate, during 2006 for the conterminous United States.

Compared to NADP deposition estimates (Fig. 6a), Fig. 6b shows higher PRISM estimates of nitrate deposition in desert regions and especially in mountainous and coastal regions of the western United States. Figure 6c shows a spatial pattern for nitrate-deposition differences for the United States between PRISM and NADP interpolations that is similar to the pattern shown for precipitation in Fig. 4, because the same NADP interpolated nitrate-concentration grid is used to estimate wet deposition for PRISM and NADP precipitation grids.

Annual PRISM deposition estimates for nitrate can exceed NADP deposition estimates by $4 \mathrm{~kg} / \mathrm{ha}$, which, coincidentally, is the critical value for nitrogen loading to Class I areas in the central Rocky Mountains proposed by Williams and Tonnessen (2000). In the Sierra Nevada, annual nitrate-deposition difference between PRISM and NADP interpolations exceed $800 \%$ per this work. Current NADP deposition estimates generated using the IDW method may be underestimating atmospheric loading to high-elevation regions and masking the exceedances of proposed critical loads to sensitive areas.

\section{Conclusions}

Improving atmospheric wet-deposition estimates of contaminants for complex terrain in the western United States is required to advance scientists' understanding of the sensitive ecology of these regions. The complexity of mountainous terrain complicates the accurate measurement of precipitation in these areas. The NADP is the only comprehensive monitoring network that provides a long-term record of precipitation concentration and analyte deposition for the nation. The NADP IDW interpolation method, used to generate isopleth maps depicting precipitation amounts, precipitation-weighted mean concentrations of chemical constituents, and analyte wet deposition, has a significant limitation in accounting for precipitation and concentration variation with elevation, which may lead to biased estimation of precipitation amounts and constituent wet deposition in complex terrain.

PRISM estimates precipitation by using data generated by high-density climatic networks across the United States and incorporates precipitation variations with elevation, providing a more spatially detailed representation of precipitation than the NADP due to the comparatively limited distribution of NADP/NTN sites in the western United States. Variations of major ion concentrations in precipitation measured by the NADP/NTN vary with elevation by small, unpredictable amounts. Ignoring the potential dependence of concentration on elevation, spatially interpolated concentration grids can be multiplied by an elevation-dependent, precipitation-depth grid to obtain more detailed and presumably more representative wet-deposition maps. In most cases, the PRISM method will increase estimated wet deposition of chemical species by as much as 2 to 4 times over the NADP-estimated deposition in the mountainous and coastal west, especially on windward sides of mountain ranges. An evaluation of algorithms to adjust spatially interpolated, precipitation constituent-concentration data grids for elevation change is needed to further improve the accuracy of wet-deposition mapping products for NADP.

\section{References}

Clow, D. W., Ingersoll, G. P., Mast, M. A., Turk, J. T., \& Campbell, D. H. (2002). Comparison of snowpack and winter wet-deposition chemistry in the Rocky Mountains, USA-Implications for winter dry deposition. Atmospheric Environment, 36(14), 2337-2348.

Daly, C. (1998). Variable influence of terrain on precipitation patterns-Delineation and use of effective terrain height in PRISM. Oregon State University. http://www. prism.oregonstate.edu/pubv/prism/docs/effectivetevrvravindaly.pdf. Accessed 01 February 2011.

Daly, C. (2006). Guidelines for assessing the suitability of spatial climate data sets. International Journal of Climatology, 26, 707-721.

Daly, C., Neilson, R. P., \& Phillips, D. L. (1994). A statistical-topographic model for mapping climatological precipitation over mountainous terrain. Journal of Applied Meteorology, 33, 140-158.

Daly, C., Taylor, G. H., Gibson, W. P., Parzybok, T. W., Johnson, G. L., \& Pasteris, P. (2001). High-quality spa- 
tial climate data sets for the United States and beyond. Transactions of the American Society of Agricultural Engineers, 43, 1957-1962.

Daly, C., Gibson, W. P., Taylor, G. H., Johnson, G. L., \& Pasteris, P. (2002). A knowledge-based approach to the statistical mapping of climate. Climate Research, 22, 99-113.

Daly, C., Halbleib, M., Smith, J. I., Gibson, W. P., Dogett, M. K., Taylor, G. H., et al. (2008). Physiographically sensitive mapping of climatological temperature and precipitation across the conterminous United States. International Journal of Climatology, 28, 2031-2064. doi:10.1002/joc.1688.

Dettinger, M., Redmond, K., \& Cayan, D. (2004). Winter orographic precipitation ratios in the Sierra NevadaLarge-scale atmospheric circulations and hydrologic consequences. Journal of Hydrometeorology, 5(6), 1102-1116.

Dore, M. H. I. (2005). Climate change and changes in global precipitation patterns-What do we know? Environment International, 31, 1167-1181.

Dossett, S. R., \& Bowersox, V. C. (1999). NADP Manual 1999-01-National trends network site operation manual. Champaign: National Atmospheric Deposition Program at the Illinois State Water Survey.

Fenn, M. E., Haeuber, R., Tonnessen, G. S., Baron, J. S., Grossman-Clarke, S., Hope, D., et al. (2003). Nitrogen emissions, deposition, and monitoring in the Western United States. BioScience, 53(4), 391-403.

Ingersoll, G. P., Turk, J. T., Mast, M. A., Clow, D. W., Campbell, D. H., \& Bailey, Z. C. (2001). Rocky Mountain snowpack chemistry network-History, methods, and the importance of monitoring mountain ecosystems. U.S. Geological Survey Open-File Report 01-466.

Kanji, H. K. (1993). 100 statistical tests. Newbury Park: Sage.

Marks, D., McGurk, B., \& Berg, N. (1988). Snow volume comparisons for atmospheric deposition monitoring. In Western snow conference, 56th annual meeting. Kalispell, Mont., April 19-21, 1988, Proceedings. Fort Collins, Colo., Colorado State University.

Munger, J. W., \& Eisenreich, S. J. (1983). Continental-scale variations in precipitation chemistry. Environmental Science and Technology, 17, 32-42.

Nanus, L., Campbell, D. H., Ingersoll, G. P., Clow, D. W., \& Mast, M. A. (2003). Atmospheric deposition maps for the Rocky Mountains. Atmospheric Environment, 37, 4881-4892.

National Acid Precipitation Assessment Program (NAPAP) (2005). National acid precipitation assessment program report to congress-An integrated assessment. National Oceanic and Atmospheric Administration. http://ny.cf.er.usgs.gov/napap/Information/ NAPAP\%20Report\%208-22-05.pdf. Accessed 01 February 2011.

National Atmospheric Deposition Program (NADP). (2008). Completeness criteria. National Atmospheric Deposition Program. http://nadp.sws.uiuc.edu/ documentation/completeness.asp. Accessed 10 June 2008.
National Atmospheric Deposition Program (NADP) (2009). National atmospheric deposition program 2008 annual summary-Illinois state water survey miscellaneous publication 189/NADP data report 200901. http://nadp.sws.uiuc.edu/lib/data/2008as.pdf. Accessed 01 February 2011.

Perry, M., \& Hollis, D (2006). The generation of monthly gridded datasets for a range of climatic variables over the United Kingdom. Met Office, Exeter, Devon, UK. http://www.metoffice.gov.uk/climate/uk/about/Monthly_ gridded_datasets_UK.pdf. Accessed 01 February 2011.

Rife, D. L. (1996). The effects of mountains and complex terrain on airflow and development of clouds and precipitation. Western Region Technical Attachment, no. 96-16. http://www.wrh.noaa.gov/wrh/ 96TAs/TA9616/ta96-16.html. Accessed 01 February 2011.

Ritter, M. E. (2006). The physical environment-An introduction to physical geography. University of Wisconsin-Stevens Point. http://www.uwsp.edu/geo/ faculty/ritter/geog101/textbook/title_page.html. Accessed 01 February 2011.

Stohlgren, T. J., Melack, J. M., Esperanza, A. M., \& Parsons, D. J. (1991). Atmospheric deposition and solute export in giant sequoia-Mixed conifer watersheds in the Sierra Nevada, California. Biogeochemistry, 12, 207-230.

Warren, W. G., Bohm, M., \& Link, D. (1992). A statistical methodology for exploring elevational differences in precipitation chemistry. Atmospheric Environment, l.c. $(26 \mathrm{~A})(1), 159-169$.

Wetherbee, G. A., Latysh, N. E., \& Burke, K. P. (2005a). External quality-assurance results for the National Atmospheric Deposition Program/National Trends Network, 2002-2003. U.S. Geological Survey Scientific Investigations Report 2005-5061.

Wetherbee, G. A., Latysh, N. E., \& Gordon, J. D. (2005b). Spatial and temporal variability of the overall error of national atmospheric deposition program measurements determined by the USGS collocated-sampler program, water years 1989-2001. Environmental Pollution, 135(2005), 407-418.

Wetherbee, G. A., Latysh, N. E., \& Greene, S. M. (2006). External quality-assurance results for the National Atmospheric Deposition Program/National Trends Network and Mercury Deposition Network, 2004. U.S. Geological Survey Scientific Investigations Report 2006-5067.

Williams, M. W., \& Tonnessen, K. A. (2000). Critical loads for inorganic nitrogen deposition in the Colorado Front Range, USA. Ecological Applications, 10(6), 1648-1665.

Williams, M. W., Bardsley, T., \& Rikkers, M. (1998). Overestimation of snow depth and inorganic nitrogen wetfall using NADP data, Niwot Ridge, Colorado. Atmospheric Environment, 32, 3827-3833.

Zerger, A. (2004). GridSampler. CSIRO Sustainable Ecosystems, Canberra, ACT, 2602, Australia. Available at: http://arcscripts.esri.com/details.asp?dbid=13712. Accessed 01 February 2011. 